Brownmiller, Susan. 1975. Against Our Will: Men, Women and Rape. New York: Simon \& Schuster.

Crenshaw, Kimberlé. 1989. "Demarginalizing the Intersection of Race and Sex." University of Chicago Legal Forum 1989(1): 139-67.

Fahey, Anna Cornelia. 2007. "French and Feminine: Hegemonic Masculinity and the Emasculation of John Kerry in the 2004 Presidential Race." Critical Studies in Media Communication 24 (2): $132-50$.

Hawkesworth, Mary. 2003. "Congressional Enactments of Race-Gender." American Political Science Review 97 (4): 529-50.

King, Deborah K. 1988. "Multiple Jeopardy, Multiple Consciousness.” Signs 14 (1): $42-72$

Krook, Mona Lena. 2017. "Violence against Women in Politics." Journal of Democracy 28 (1): 74-88.

Krook, Mona Lena, and Juliana Restrepo Sanín. 2016. "Violence against Women in Politics: A Defense of the Concept." Politica y Gobierno 23 (2): 459-90.

Kuperberg, Rebecca. 2017. "Sexual Violence against Women in Politics." Unpublished manuscript.

McCall, Leslie. 2005. "The Complexity of Intersectionality." Signs 30 (3): 1771-1800.

Tormos, F. 2017. "Intersectional Solidarity." Politics, Groups and Identities 5 (4): 707-20. Yuval-Davis, Nira. 2006. "Intersectionality and Feminist Politics." European Journal of Women's Studies 13 (3): 193-209.

\title{
Making Gender Visible in Election Violence: Strategies for Data Collection
}

\section{Elin Bjarnegård, Uppsala University}

doi:10.1017/S1743923X18000624

Election violence is an important issue from a number of perspectives. Understanding the causes and consequences of violations of personal integrity is always relevant, but election violence adds a different dimension to this already serious issue: it also violates electoral integrity and decreases democratic quality (Norris 2013). Therefore, election violence should be studied as a simultaneous violation of personal and electoral integrity. In this contribution, I define election violence as occurring when (1) the goal of the act is to affect an electoral outcome or prevent someone from running in an election, and (2) the means by which it is carried out violates the personal integrity of individuals involved in the electoral process.

From existing research on gender and violence, we know that men and women are prone to fall victim to different types of violations of personal 
integrity. It is likely that gendered differences in prevalence and forms of violence also prevail in the electoral sphere, but studies hitherto have not been designed to adequately capture them. By merging insights about violations of electoral integrity, on the one hand, with insights about gender-based violence, on the other, we can begin to devise strategies for data collection on election violence that takes into account its relevant gender aspects. Drawing on pilot study research conducted in the Maldives and Myanmar within my ongoing project, Gender Aspects of Election Violence, I point to specific ways in which data collection can move forward in this regard. I argue that the different experiences that women and men may have of election violence will be better captured by looking for a variety of forms of violence while at the same time not limiting the pool of potential types of respondents to either victims or to victims of a certain sex.

\section{FORMS OF VIOLENCE}

Personal integrity can be violated in different ways, through acts of intimidation, threats, or physical violence. All such violations of personal integrity can be carried out with the intent to severely disturb or illegitimately affect the democratic process. The range of activities defined as election violence are broad, therefore, and should not be confined to an exclusive focus on physical violence. Yet while there is general theoretical agreement that election violence can take many different forms beyond physical violence, including harassment, intimidation, destruction of property, and abuse (see, e.g., Fischer 2002, 3; Höglund 2009, 417), this is seldom reflected in actual empirical investigations of the subject. Moreover, research on election violence has, with few exceptions, been conducted at the aggregate level, focusing on countries and incidents rather than individual experiences. Data has often been collected from electoral management bodies, election observers, or secondary sources such as media reports (Daxecker 2012; Höglund 2009; Hyde and Marinov 2012). The result has been a bias toward visible, physical acts of violence taking place in the public sphere.

From studies of violence outside the electoral sphere, we know that men are more likely than women to be the victims of physical and fatal violence. The violence that men experience tends to take place in public and is often committed by a perpetrator unknown to them. In contrast, violence against women is more likely to take the form of psychological violence, or 
nonlethal physical sexual violence. It is more often perpetrated by a spouse or an individual known to them, and it generally takes place less openly, often in the home (Bjarnegård et al. 2015; UNODC 2013; WHO 2013). It thus seems likely that most studies of election violence to date are inadvertently designed to capture a "masculine" experience of violence, while the "feminine" experience of violence that is not observable, because it is not visible to outsiders, not reported, or does not take place in public spaces, is not included. These gendered patterns are likely to be accentuated in cases of election violence. Perpetrators who use violence against individuals in order to affect the outcome of an election are likely to choose the most cost-effective form of violence to achieve that end. The gender of the person targeted may well affect such calculations. Perpetrators may surmise that spreading rumors about a politically active woman is a comparatively efficient way of affecting her behavior and is also connected with significantly lower risk compared with a physical attack.

Designing studies of election violence so that they can capture both physical violence and psychological violence is a first step to better capture these gendered aspects (see also Bardall 2011; Krook and Restrepo Sanín 2016a). This implies explicitly asking about violations of personal integrity beyond physical violence. Knowing that only a small share of the violence women experience takes place in the open, it is also important to explore new, safe, and ethical strategies for obtaining information about incidents occurring in the private sphere. In a report on community-based monitoring data collected in six countries by the International Foundation for Electoral Systems, Bardall (2011) revealed a higher level of election violence conducted against women than is usually found in public sources, suggesting that electoral violence against women is generally underreported. The report also suggested that election violence does indeed mirror gendered patterns from outside of the political sphere: while female victims of election violence most often reported intimidation and psychological abuse, male victims typically reported physical violence taking place in the public sphere. Similar gendered patterns emerge in surveys and interviews I have conducted with political candidates in the Maldives and Myanmar. I found that women candidates were disproportionately the victims of psychological violence, particularly in the form of libel and rumors with sexual connotations. The location in which these violations of personal integrity took place was often social media: a "new" sphere, challenging 
both neat distinctions between public and private as well as conventional methods of geographic mapping of violent incidences.

\section{TYPES OF RESPONDENTS}

In order to improve our knowledge of the gendered aspects of election violence, I argue that potential respondents should not be limited a priori to victims of election violence or to female victims of election violence. Even if women as victims are at the center of the analysis, understanding what differentiates victims from nonvictims, and female victims from male victims, is key for understanding whether and how gender plays a part. This requires a more inclusive strategy for the selection of respondents.

Literature on election violence specifies a wide range of targets, not even limited to people but including election data, buildings, facilities, and events (Fischer 2002, 9; Höglund 2009, 417). When election violence is conceptualized as a violation of personal integrity, potential victims are limited to a range of political stakeholders. Research on political violence, both gender-blind and gender-sensitive, however, often moves beyond incidents to focus on affected individuals. When we document only the experiences of those who have experienced violations of personal integrity for electoral reasons, however, it becomes impossible to measure prevalence. In order to achieve measurable variation, research should focus instead on a specific population with a particular function in relation to the election, a population that potentially includes individuals with and without experiences of violence, such as voters, election workers, party supporters, candidates, and journalists.

Emerging research on gender and political violence tends to collect information from an even further limited population: female victims only. Men as victims of violence have been largely left out of the picture, and often explicitly so. Research in the field is often referred to as research on "violence against women in politics" (Krook and Restrepo Sanín 2016b; see also Krook 2017). Although the focus on women partly stems from an understanding that research on election violence is biased toward the experiences of men, it is unfortunate that the same-gender bias in now being repeated in reverse.

Comparing the experiences of men and women, I suggest, can bring about useful knowledge and, indeed, this is the only way in which we can investigate gender differences in election violence prevalence. 
Focusing only on women's experiences of violence does not allow us to distinguish between instances of violence in which gender is part of the motive versus contexts in which violence is widespread and affects all political actors. As the proportion of women in politics increases in contexts in which political violence is normalized and seen as a way of doing politics, the number of women who are victims will inevitably increase (Piscopo 2016), yet it remains an open empirical question whether overall rates of election violence against politicians will increase.

Together with an analysis of different forms of violence, explicit comparisons between men and women will unveil how vulnerabilities may be differentiated based on gender. The experiences of men are often seen as the norm and are thus not problematized or scrutinized in gendered analyses (Bjarnegård 2013). However, the fact that men may be more likely victims of (certain forms of) violence in some contexts is also a highly gendered phenomenon that needs to be understood. For instance, in the Myanmar context, all candidates experienced rumors being spread on social media. The content of these rumors, however, mapped on to existing stereotypes of men and women. While it was suggested that some men were secretly Muslim, women were often accused of promiscuity.

\section{TWO STRATEGIES FOR DATA COLLECTION ON GENDER AND ELECTION VIOLENCE}

To summarize, the way forward if we are to merge insights from research on electoral integrity with research on gender and political violence is to situate our questions at the intersection of electoral and personal integrity. This implies two strategies for improved comparative research designs: (1) expanding the operational definition of election violence beyond communal, physical violence and (2) identifying our respondents by their status in relation to the election, thus including both men and women as well as both victims and nonvictims.

Elin Bjarnegård is Associate Professor of Government at Uppsala University, Uppsala, Sweden: elin.bjarnegard@statsvet.uu.se

\section{REFERENCES}

Bardall, Gabrielle. 2011. Breaking the Mold: Understanding Gender and Electoral Violence. Washington, DC: International Foundation for Electoral Systems. 
Bjarnegård, Elin. 2013. Gender, Informal Institutions and Political Recruitment. Basingstoke: Palgrave Macmillan.

Bjarnegård, Elin, Erik Melander, Gabrielle Bardall, Karen Brounéus, Erika Forsberg, Karin Johansson, Angela Muvumba Sellström, and Louise Olsson. 2015. "Gender, Peace and Armed Conflict." In SIPRI Yearbook 2015. Oxford: Oxford University Press, 101-9.

Daxecker, Ursula E. 2012. "The Cost of Exposing Cheating: International Election Monitoring, Fraud, and Post-election Violence in Africa." Journal of Peace Research 49 (4): $503-16$.

Fischer, Jeff. 2002. Electoral Conflict and Violence. Washington, DC: International Foundation for Electoral Systems.

Hyde, Susan, and Nikolay Marinov. 2012 "Which Elections Can Be Lost?" Political Analysis 20 (2): 191-201.

Höglund, Kristine. 2009. "Electoral Violence in Conflict-Ridden Societies." Terrorism and Political Violence 21 (3): 412-27.

Krook, Mona Lena. 2017. "Violence against Women in Politics." Journal of Democracy 28 (1): 74-88.

Krook, Mona Lena, and Juliana Restrepo Sanín. 2016a. "Gender and Political Violence in Latin America.” Politica y Gobierno 23 (1): 125-57.

- 2016b. "Violence against Women in Politics: A Defense of the Concept." Politicay Gobierno 23 (2): 459-90.

Norris, Pippa. 2013. “The New Research Agenda Studying Electoral Integrity.” Electoral Studies 32 (4): $563-75$.

Piscopo, Jennifer. 2016. "State Capacity, Criminal Justice, and Political Rights: Rethinking Violence against Women in Politics." Politica y Gobierno 23 (2): 437-58.

United Nations Office on Drugs and Crime (UNODC). 2013. "Global Study on Homicide 2013." https://www.unodc.org/documents/data-and-analysis/statistics/GSH2013/2014_ GLOBAL_HOMICIDE_BOOK_web.pdf (accessed August 20, 2018).

World Health Organization (WHO). 2013. "Global and Regional Estimates of Violence against Women." http://www.who.int/reproductivehealth/publications/violence/97892 41564625/en/ (accessed August 20, 2018).

\section{Turning the Tide on Violence against Women in Politics: How Are We Measuring Up?}

\section{Julie Ballington, UN Women}

doi:10.1017/S1743923X18000636

Violence against women in politics (VAWP) is a human rights violation, as it prevents the realization of political rights. Violence against women in political and public life can be understood as "any act or threat of

This article has benefited from contributions by Gabriella Borovsky. 